\title{
High Hydrostatic Pressure Modification of Whey Protein Concentrate for Improved Functional Properties
}

\author{
S.-Y. Lim, B. G. Swanson, and S. Clark ${ }^{1}$ \\ Department of Food Science and Human Nutrition, Washington State University, Pullman 99164-6376
}

\begin{abstract}
Whey protein concentrate (WPC) has many applications in the food industry. Previous research demonstrated that treatment of whey proteins with high hydrostatic pressure (HHP) can enhance solubility and foaming properties of whey proteins. The objective of this study was to use HHP to improve functional properties of fresh WPC, compared with functional properties of reconstituted commercial whey protein concentrate 35 (WPC 35) powder. Fluid whey was ultrafiltered to concentrate proteins and reconstituted to equivalent total solids (8.23\%) as reconstituted commercial WPC 35 powder. Solutions of WPC were treated with 300 and $400 \mathrm{MPa}$ (0- and 15-min holding time) and 600 $\mathrm{MPa}$ (0-min holding time) pressure. After HHP, the solubility of the WPC was determined at both $\mathrm{pH} 4.6$ and 7.0 using UDY and BioRad protein assay methods. Overrun and foam stability were determined after protein dispersions were whipped for $15 \mathrm{~min}$. The protein solubility was greater at $\mathrm{pH} 7.0$ than at $\mathrm{pH} 4.6$, but there were no significant differences at different HHP treatment conditions. The maintenance of protein solubility after HHP indicates that HHP-treated WPC might be appropriate for applications to food systems. Untreated WPC exhibited the smallest overrun percentage, whereas the largest percentage for overrun and foam stability was obtained for WPC treated at $300 \mathrm{MPa}$ for $15 \mathrm{~min}$. Additionally, HHP-WPC treated at $300 \mathrm{MPa}$ for 15 min acquired larger overrun than commercial WPC 35. The HHP treatment of $300 \mathrm{MPa}$ for 0 min did not improve foam stability of WPC. However, WPC treated at 300 or $400 \mathrm{MPa}$ for $15 \mathrm{~min}$ and $600 \mathrm{MPa}$ for $0 \mathrm{~min}$ exhibited significantly greater foam stability than commercial WPC 35 . The HHP treatment was beneficial to enhance overrun and foam stability of WPC, showing promise for ice cream and whipping cream applications.
\end{abstract}

Received May 25, 2007.

Accepted October 29, 2007.

${ }^{1}$ Corresponding author: stephclark@wsu.edu
Key words: whey protein concentrate, high hydrostatic pressure, protein solubility, foam stability

\section{INTRODUCTION}

Whey and whey products have been used successfully in the food industry for years. Whey proteins increase milk solids nonfat, are highly soluble, and improve nutritional value, foaming, and emulsification properties of ice cream and frozen desserts (Morr and Ha, 1993; Hoffman, 1996; Jayaprakasha and Brueckner, 1999; Young, 1999).

Traditional food processing methods rely on high temperatures to ensure food safety and prolonged shelf life. However, heat treatment at high temperatures can result in detrimental changes in the processed products (Martin et al., 2002). The changes result in products that are far from similar to original fresh products. These undesirable changes affect nutritional attributes as well as protein denaturation, which decreases protein solubility and foaming properties of whey proteins (Parris and Baginski, 1991; Martin et al., 2002). Moreover, severe thermal treatments (above $70^{\circ} \mathrm{C}$ ) result in protein denaturation, accompanied by loss of aqueous solubility and foaming properties (Kester and Richardson, 1984). Whey protein concentrate (WPC) is available commercially in a variety of forms. Commercial whey protein concentrate 35 (WPC 35) contains a minimum of $35 \%$ protein and undergoes a spray-drying process to produce a powder. Proteins in WPC 35 powder typically experience temperatures greater than $75^{\circ} \mathrm{C}$ and are denatured. Heat denaturation at high temperature, greater than $75^{\circ} \mathrm{C}$, generally results in negative effects on the functional properties of the protein: emulsifying capacity and foaming properties are commonly reduced (Pittia et al., 1996). Improvements in functional properties may be achieved by modifying the protein structure using physical treatments instead of heat (Kato et al., 1983).

High hydrostatic pressure (HHP) is receiving attention as an alternative to thermal processing. Small protein concentrations and pressures up to 200 to $300 \mathrm{MPa}$ usually result in reversible pressure-induced partial denaturation. High pressures greater than $500 \mathrm{MPa}$ 
result in irreversible and extensive effects on proteins, including denaturation due to unfolding of monomers, aggregation, and formation of gels (Balny et al., 1989). Relatively high-pressure treatment (greater than 300 $\mathrm{MPa}$ for more than $30 \mathrm{~min}$ ) of the primary whey protein, $\beta$-LG, induces irreversible denaturation, which results in increased hydrophobicity and formation of protein aggregates (Pittia et al., 1996). Simultaneously, the exposure of previously buried hydrophobic and $\mathrm{SH}$ groups by pressure treatment results in structural changes of proteins and increases flexibility more than heat treatment.

Yang et al. (2001) stated that HHP treatment at 600 $\mathrm{MPa}$ at $50^{\circ} \mathrm{C}$ induced $\beta$-LG to form a stable molten globule state, intermediate between the native state and the completely denatured state. The molten globule state of $\beta$-LG exhibits high affinity with hydrophobic probes when compared with the native state of $\beta$-LG. Because HHP treatment results in increased accessibility of the buried $\mathrm{SH}$ groups, $\mathrm{SH}$ oxidation occurs during or after high-pressure treatment of $\beta$-LG (Yang et al., 2001). The HHP-induced $\beta$-LG dimers tend to be surrounded by hydrophobic AA residues, resulting in an increase of hydrophobic affinity of $\beta$-LG at the surface hydrophobic sites (Yang et al., 2003). The pressure treatment probably induces partially reversible unfolding of the $\beta$-LG, resulting in the unmasking of buried hydrophobic groups and an increase in the hydrophobicity of the protein. Thus, pressure treatment results in an increase in hydrophobicity of $\beta$-LG, an expected enhancement of some functionality in food systems.

If functional properties of whey proteins are enhanced, whey proteins will provide desirable functionality to a wide range of food products, including improved appearance, body, texture, and consistency. One of the most important physicochemical and functional properties of whey proteins is solubility (Morr and Ha, 1993). Protein solubility depends on various physicochemical properties, including molecular weight, secondary and tertiary structure, hydrophobicity, and electrostatic charge (Morr and Ha, 1993). Processing treatments used to manufacture WPC may result in heatinduced protein denaturation, which then reduces whey protein solubility. Native whey proteins remain soluble at around $\mathrm{pH} \mathrm{7;} \mathrm{however,} \mathrm{heat-induced} \mathrm{denaturation}$ renders whey proteins less soluble than native whey proteins (Morr and Ha, 1993). Thus, protein solubility of WPC is useful for estimating protein denaturation (Morr and Foegeding, 1990). Protein solubility did not decrease in 6\% whey protein isolate (WPI) solution after HHP at $400 \mathrm{MPa}$ for 10 min compared with untreated 6\% WPI solution (Kanno et al., 1998). However, Lee et al. (2006) reported that the solubility of $1 \%$ WPC decreased as HHP treatment time increased from 5 to $30 \mathrm{~min}$ at $690 \mathrm{MPa}$. Because protein solubility depends on HHP treatment conditions, careful selection of HHP treatment conditions are important to maintain protein solubility in potential food product formulations.

Enhancement of foaming properties can potentially reduce the cost of production, because less protein is necessary to provide desired functionality. Studies were conducted with reconstituted WPI or WPC to understand the effect of HHP on emulsifying and foaming properties of whey proteins. Ibanoglu and Karatas (2001) reported that WPI treated with HHP at $300 \mathrm{MPa}$ exhibited greater foam stability than untreated WPI, but foam stability of WPI decreased at pressures greater than $300 \mathrm{MPa}$. Foaming properties of $\beta$-LG were enhanced at $300 \mathrm{MPa}$ for $10 \mathrm{~min}$, which was attributed to an increase of hydrophobicity (Pittia et al., 1996). However, the reduction in foam stability at greater than $300 \mathrm{MPa}$ may be explained as the detrimental effect of unfolding due to the increase in hydrophobicity of $\beta$ LG upon high-pressure treatment (Pittia et al., 1996). Unfolding of proteins lessens viscoelasticity of a film with a reduced number of interactions between molecules (Ibanoglu and Karatas, 2001). The HHP-treated WPC contributes to an increase in emulsion stability of model oil-in-water emulsions; WPC treated at 690 MPa for 5 min exhibited increased emulsifying activity (Lee et al., 2006). The HHP treatment of WPC results in an increase of the surface hydrophobicity, attributed to the molten globule state, resulting in partial unfolding of whey proteins (Liu et al., 2005; Lee et al., 2006). The molten globule state may be attributed to hydrophobic patch stabilization at air-water interfaces of whey proteins to increase the foam stability of whey proteins. The molten globule state resulting from HHP treatment retains protein solubility and increases hydrophobicity to enhance foam stability of whey proteins. The HHP-treated whey proteins may have a potential for formulated food products requiring protein solubility and functional properties.

Fat content plays an important role in food products requiring foaming properties. Fat may form a matrix of partially coalesced fat that contains air bubbles. Foods with high fat content create foams. As fat content decreases, foams become soft and unstable (Hercules Technical Information, 2006). Thus, reduced-fat foods make unstable foams compared with regular-fat foods, but reducing the fat content in foods may offer a variety of benefits, including cost and calorie savings. An HHPtreated WPC may be appropriate to serve as a fat replacer if the solubility of WPC is maintained. Moreover, $\mathrm{HHP}$ is expected to increase surface hydrophobicity and contribute to enhance foaming properties (Ibanoglu and Karatas, 2001; Liu et al., 2005; Lee et al., 2006). How- 
Table 1. Composition of diluted fresh WSU-WPC compared with reconstituted commercial WPC 35

\begin{tabular}{lcc}
\hline Composition & $\begin{array}{c}\text { WSU-WPC } \\
(\%)\end{array}$ & $\begin{array}{c}\text { WPC } 35^{2} \\
(\%)\end{array}$ \\
\hline Total solids & 8.23 & 8.23 \\
Protein & 3.02 & 3.06 \\
Fat & 0.28 & 0.26 \\
Lactose & 4.24 & 4.18 \\
\hline
\end{tabular}

${ }^{1}$ Washington State University-whey protein concentrate.

${ }^{2}$ Commercial whey protein concentrate 35 .

ever, previous studies utilized reconstituted WPC or WPI powders that could have been completely denatured by spray-drying. Little research is available regarding the effect of HHP on functional properties of fresh whey proteins.

Fresh sweet whey ultrafiltration (UF) retentate, called Washington State University WPC (WSU-WPC), was utilized in this research, because it was hypothesized that WPC prepared from fresh fluid whey will have better functionality than reconstituted spraydried WPC 35. Ultimately, this study was designed to evaluate protein solubility and foaming properties of WSU-WPC after HHP, a step toward determining if HHP treatment of fresh WPC is appropriate for reduced-fat foods such as ice cream and whipping cream.

\section{MATERIALS AND METHODS}

Sweet whey from Cheddar cheese-making at the Washington State University (WSU) Creamery (Pullman) was ultrafiltered and diluted to about $8.23 \%$ total solids and $3.02 \%$ protein content (Table 1 ). The endproduct is identified as WSU-WPC. Commercial WPC 35 powder from Foremost Farms (Baraboo, WI) was reported to contain $35.7 \%$ protein, $3.2 \%$ fat, $51.1 \%$ lactose, and 96\% total solids, based on powder (Table 1). The WPC 35 powder was reported to have been pasteurized at a temperature above $75^{\circ} \mathrm{C}$ for at least $15 \mathrm{~s}$, followed by spray-drying below $100^{\circ} \mathrm{C}$. The WPC 35 was reconstituted to $8.23 \%$ total solids and $3.06 \%$ protein (Table 1). The WPC 35 with the same lot number was used throughout experiments of functional properties, whereas triplicate batches of WSU-WPC were produced by UF to maintain freshness. Standard proteins for SDS-PAGE were obtained from BioRad Laboratories (Hercules, CA).

\section{UF of Whey}

Before UF, the whey was pasteurized at $63^{\circ} \mathrm{C}$ for 30 min and cooled to $40.5^{\circ} \mathrm{C}$ in a jacketed kettle (Groen Div/Dover Corporation, Elf Grove Village, IL). The UF was conducted in the pilot plant of the WSU Food Sci- ence and Human Nutrition Department using a UF unit (Romicon Inc., Woburn, MA) with a 50.8-mm, 5$\mu \mathrm{m}$ PM-10 hollow fiber (Koch Membrane Systems Inc, Wilmington, MA). Ultrafiltration was carried out at $40.5^{\circ} \mathrm{C}$ and at pressures of $172.37 \mathrm{kPa}$ inlet and 34.47 $\mathrm{kPa}$ outlet. Based on the protein content of the whey (0.75 to $0.80 \%)$, the WPC was concentrated to an equivalent protein content (about 3\%) as the WPC 35. The UF was stopped when the volume of permeate collected was $75 \%$ of the original volume. Ultrafiltered fresh WPC (WSU-WPC) was pasteurized at $68^{\circ} \mathrm{C}$ for $30 \mathrm{~min}$ and cooled to $10^{\circ} \mathrm{C}$ in the kettle with intermediate occasional stirring. The WSU-WPC is different from WPC 35 powder in that WPC 35 was heated during spraydrying to greater than $75^{\circ} \mathrm{C}$, which yields a fully denatured product. The total solids were determined by drying samples of the UF whey at $105^{\circ} \mathrm{C}$ for $12 \mathrm{~h}$. The total solids of the WPC were standardized to $8.23 \%$ by adding distilled water, cooled to less than $10^{\circ} \mathrm{C}$. The WSUWPC was studied immediately or stored at $4^{\circ} \mathrm{C}$ for less than 2 wk.

\section{Pressurization of WSU-WPC}

Portions of WSU-WPC were volumetrically poured into separate Lay-Flat Poly Tubing (Consolidated Plastics Company Inc., Twinsburg, $\mathrm{OH}$ ), $5.3-\mathrm{cm}$ wide, $4-\mathrm{mm}$ thick, cut to desired length, and heat-sealed at both ends. Bags of WSU-WPC were treated with 300 and $400 \mathrm{MPa}(0-$ or 15 -min holding time) and $600 \mathrm{MPa}(0-$ min holding time), at an initial temperature of $25^{\circ} \mathrm{C}$ in a warm isostatic press (Engineered Pressure Systems Inc., Haverhill, MA) with a cylindrical pressure chamber (height $=0.25 \mathrm{~m}$, diameter $=0.10 \mathrm{~m}$ ). Untreated WSU-WPC and WPC 35 solutions served as controls. The zero holding time indicates the come-up time, the compression time required to reach a pressure of 300 , 400 , or $600 \mathrm{MPa}$. After exposure to HHP, the solutions were studied immediately or stored at $4^{\circ} \mathrm{C}$ for less than 2 wk.

\section{Protein Solubility Test}

Protein solubility is used to identify the extent of whey protein denaturation. Morr et al. (1985) developed a reliable procedure for determining the solubility of food proteins. The $\mathrm{pH}$ of untreated WSU-WPC, WPC 35, and HHP-treated WSU-WPC solutions were adjusted to pH 4.6 or 7.0 with $0.1 N \mathrm{HCl}$ or $0.1 \mathrm{~N} \mathrm{NaOH}$ solutions, respectively. An aliquot of the solutions was centrifuged for $30 \mathrm{~min}$ at $20,000 \times \mathrm{g}$, and the resulting supernatant fraction was filtered through Whatman No. 1 filter paper (Morr et al., 1985). The protein content of the filtrate was determined by both the UDY method (AOAC, 
1990), modified for whey analysis, and the BioRad protein assay method (Bradford, 1976). Protein content, using the BioRad protein assay method, was determined after calibration with 5 dilutions of protein standards, including BSA as the external standard. The linear range of the assay was 0.1 to $1.0 \mathrm{mg} / \mathrm{mL}$. Protein solubility (PS) is expressed as a percentage of the total protein content of the dispersion before centrifugation (Lee et al., 1992). Each analysis was performed in triplicate: $\mathrm{PS}=\%$ protein, supernatant $/ \%$ protein, total $\times 100$.

\section{Overrun}

The HHP-treated WSU-WPC, untreated WSU-WPC, and WPC 35 dispersions were adjusted to $\mathrm{pH} 7.0$ with $0.1 \mathrm{~N} \mathrm{NaOH}$. A pH of 7.0 was selected, because the proteins are soluble and consistently form acceptable foams at this $\mathrm{pH}$, suitable for determination of overrun and foam stability. Foams were formed by whipping the protein solutions in a household-type mixer (KitchenAid mixer, St. Joseph, MI) at cold temperature (from 4 to $\left.10^{\circ} \mathrm{C}\right)$. The WPC dispersion $(200 \mathrm{~mL})$ was weighed and whipped for $15 \mathrm{~min}$ for overrun determinations. During foam formation, the mixer was stopped at 5min intervals to determine overrun at each time. The mixer head was carefully lifted to minimize destruction of the foam, and the weight of $200 \mathrm{~mL}$ was noted (Phillips et al., 1990). Each analysis was performed in triplicate. The overrun was calculated by the following equation: $\%$ overrun $=($ wt $200-\mathrm{mL}$ dispersion $)-($ wt $200-\mathrm{mL}$ foam $) /($ wt 200 of $\mathrm{mL}$ foam $) \times 100$.

\section{Foam Stability}

A plastic whipping bowl was modified by drilling a $0.33-\mathrm{cm}$ hole in the side of the bowl, $5.23 \mathrm{~cm}$ from the bowl bottom ridge. The hole was sealed before whipping by placing tape over the hole on the outside of the bowl. Whipping was started at the calibrated setting for a specified time (e.g., 5, 10, or $15 \mathrm{~min}$ ). After whipping, the tape was quickly removed at time zero, and a timer was started. The drained liquid was collected by tilting the bowl to the hole above a tared container on a balance pan, and the time at which 50\% drainage was observed was recorded. The time to attain 50\% drainage of the initial weight was used as an index of foam stability (Phillips et al., 1990).

\section{SDS-PAGE}

Sodium dodecyl sulfate-PAGE (10 and 4 to 20\%), without and with $\beta$-mercaptoethanol ( $\beta$-ME), was used for identifying effects of HHP treatment on each constituent protein of WPC according to the instruction man- ual of Ready Gel Precast Gels (catalog number 1610993, BioRad Laboratories). Because a gradient gel (4 to $20 \%$ ) presents a wide range of molecular weights (MW; 10 to $200 \mathrm{kDa}$ ), and a single-percentage gel (10\%) produces the greatest resolution of a narrow range of MW (30 to $200 \mathrm{kDa}$ ), the 10\% SDS-PAGE gel allowed observance of more clear whey protein bands than the gradient gel (4 to $20 \%$ ).

One milliliter of the untreated WSU-WPC, WPC 35, or HHP-treated WSU-WPC solutions was diluted with 5 $\mathrm{mL}$ of $0.5 M$ Tris- $\mathrm{HCl}$ ( $\mathrm{pH} 6.8$ ), containing $20 \%$ glycerol, $0.01 \%$ bromophenol blue, and $10 \%$ SDS. Before analysis, solutions were heated for $3 \mathrm{~min}$ in a $100^{\circ} \mathrm{C}$ water bath, followed by cooling to room temperature with running tap water. Whey proteins of 1:5 dilution $(20 \mu \mathrm{L})$, without $\beta$-ME, were loaded onto a $10 \%$ Ready Gel. Four lanes (1 standard, 3 whey proteins) of electrophoresis were run at ambient temperature for $40 \mathrm{~min}$ at $200 \mathrm{~V}$. Duplicate whey proteins of equivalent dilution, with $\beta$ ME, were loaded onto a different $10 \%$ Ready Gel. The equivalent samples, without and with $\beta$-ME, were also loaded onto 4 to $20 \%$ Ready Gels. Seven lanes (1 standard, 3 whey proteins, with and without $\beta$-ME) of electrophoresis were run under the equivalent conditions to the $10 \%$ Ready Gel. The gels were stained with a Coomassie Brilliant Blue solution containing $40 \%$ methanol, $7 \%$ acetic acid, and $0.05 \%$ Coomassie Brilliant Blue R-250 and were then destained with a $40 \%$ methanol and $7 \%$ acetic acid solution. Molecular weights of the protein bands were estimated by comparison to prestained SDS-PAGE standards (catalog number 161-0318, BioRad Laboratories). The protein standards included myosin (204 kDa), $\beta$-galactosidase (119 $\mathrm{kDa})$, BSA $(100 \mathrm{kDa})$, ovalbumin $(52.0 \mathrm{kDa})$, carbonic anhydrase $(37.4 \mathrm{kDa})$, soybean trypsin inhibitor (29.1 $\mathrm{kDa})$, lysozyme $(19.5 \mathrm{kDa})$, and aprotinin $(7.0 \mathrm{kDa})$.

\section{Statistical Analysis}

Fresh WSU-WPC was processed in 3 different batches, and each analysis was conducted in triplicate. The ANOVA test for significant effects of treatments and assays was determined using the GLM procedure (PROC GLM) in SAS (SAS Institute, 1999). Main effect differences were considered significant at the $P \leq 0.05$ level. Mean separations were determined by Tukey's procedure for multiple comparisons.

\section{RESULTS AND DISCUSSION}

\section{Protein Solubility}

In general, the solubility of WPC 35 and WSU-WPC was significantly greater at $\mathrm{pH} 7.0$ than at $\mathrm{pH} 4.6$, as indicated by both UDY protein and BioRad protein 


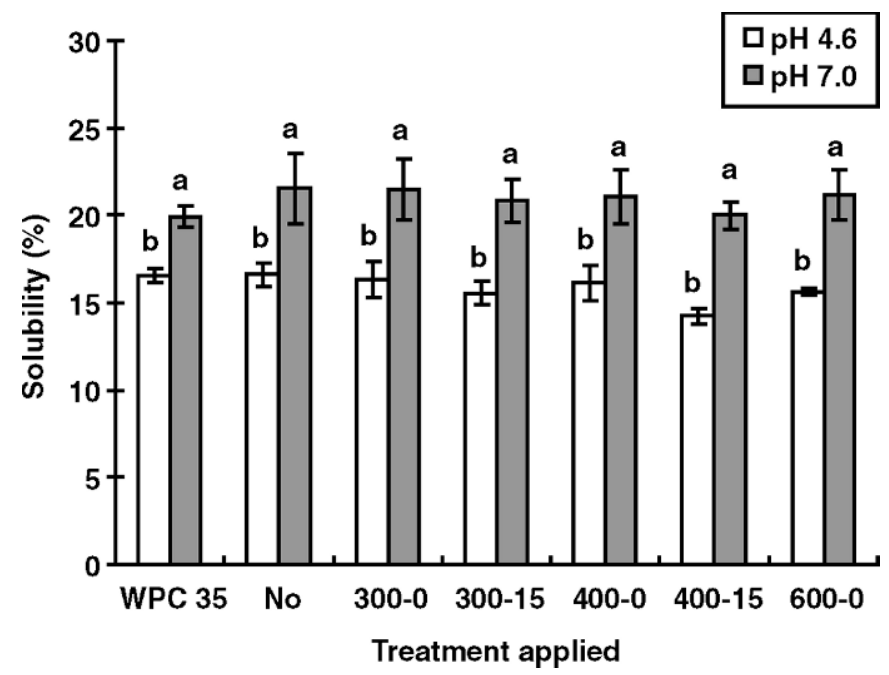

Figure 1. Protein solubility of commercial whey protein concentrate 35 [WPC 35; no high hydrostatic pressure (HHP)] or Washington State University-whey protein concentrate $($ No $=$ no HHP; $300-0=$ $300 \mathrm{MPa}$ for $0 \mathrm{~min}$; $300-15=300 \mathrm{MPa}$ for $15 \mathrm{~min} ; 400-0=400 \mathrm{MPa}$ for $0 \mathrm{~min} ; 400-15=400 \mathrm{MPa}$ for $15 \mathrm{~min} ; 600-0=600 \mathrm{MPa}$ for $0 \mathrm{~min}$ ) after selected HHP-time combinations at $\mathrm{pH} 4.6$ and 7.0, determined with the UDY method. ${ }^{\mathrm{a}, \mathrm{b}}$ Different letters denote significant differences across different treatments $(P \leq 0.05)$. Vertical lines correspond to standard deviation.

assay methods ( $P \leq 0.05$, Figures 1 and 2$)$. This is not surprising, because the $\mathrm{pH}$ of the solvent determines the nature and the distribution of net charge of proteins. A protein usually exhibits the least solubility at the isoelectric point (Pelegrine and Gasparetto, 2005). At $\mathrm{pH} 4.6$, near the isoelectric point of WPC, the net charge is minimized, and, consequently, less water interacts with the protein molecules. Decrease of water-protein binding results in aggregation of protein molecules, possibly precipitation, and poor solubility at $\mathrm{pH} 4.6$. Although solubility of WPC was significantly smaller at $\mathrm{pH} 4.6$ than 7.0, WPC is still used regularly in low$\mathrm{pH}$ applications.

Although Lee et al. (2006) reported that HHP decreased the solubility of whey proteins, the treatment conditions (690 MPa for greater than $5 \mathrm{~min}$ ) were more severe than our treatment conditions (300 $\mathrm{MPa}$ for $15 \mathrm{~min})$. In the present study, the solubility of WPC did not change significantly under selected pressure and time treatments $(P>0.05)$ at either $\mathrm{pH}$. Also, protein solubility of native or HHP-treated WSU-WPC did not significantly differ from WPC 35 . These results confirm Bouaouina et al. (2006), who reported that dynamic high-pressure treatment (50 to $300 \mathrm{MPa}$ ) did not affect whey protein solubility $(88 \% \pm 1 \%)$ for either native or treated protein solutions. Solubility of protein is a critical factor in the acceptability of dairy beverages, ice cream mix, and whipping cream. If the solubility

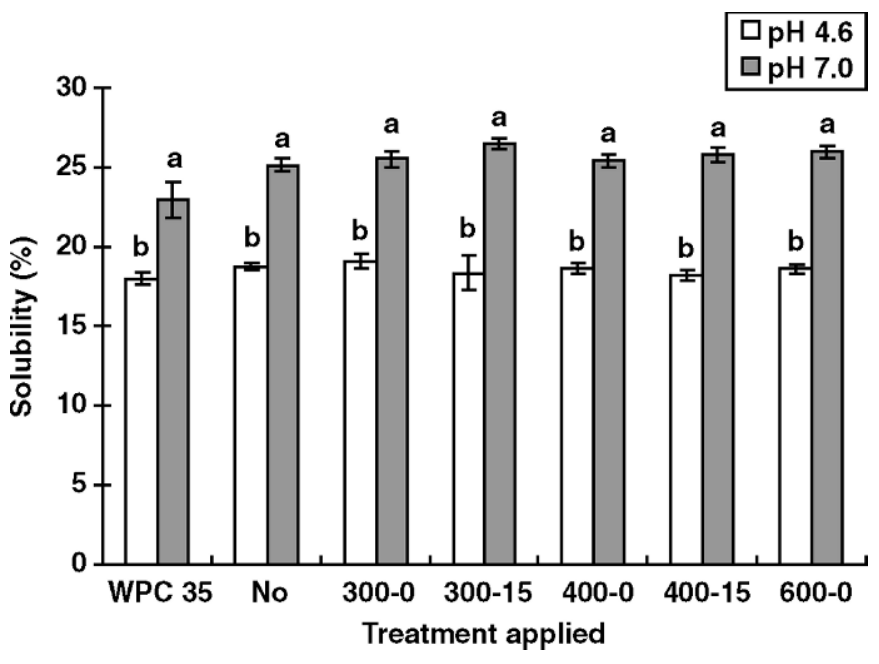

Figure 2. Protein solubility of commercial whey protein concentrate 35 [WPC 35; no high hydrostatic pressure (HHP)] or Washington State University-whey protein concentrate $(\mathrm{No}=$ no HHP; 300-0 = $300 \mathrm{MPa}$ for $0 \mathrm{~min}$; 300-15 = $300 \mathrm{MPa}$ for $15 \mathrm{~min}$; $400-0=400 \mathrm{MPa}$ for $0 \mathrm{~min} ; 400-15=400 \mathrm{MPa}$ for $15 \mathrm{~min} ; 600-0=600 \mathrm{MPa}$ for $0 \mathrm{~min}$ ) after selected HHP-time combinations at $\mathrm{pH} 4.6$ and 7.0, determined with the BioRad protein assay method. ${ }^{a, b}$ Different letters denote significant differences across different treatments $(P \leq 0.05)$. Vertical lines correspond to standard deviation.

is not decreased after HHP, applications to the food industry are promising. Thus, it is appropriate to use HHP-treated WSU-WPC in similar applications as the commercial WPC 35.

\section{Foaming Properties at Selected Pressure-Time Combinations}

High pressure and treatment time are 2 important parameters affecting the foaming properties of food proteins (Halling, 1981). According to Ibanoglu and Karatas (2001), increase in both HHP and treatment times improved the foaming ability of WPI at $\mathrm{pH}$ 7. They suggested that HHP increased protein molecule flexibility; partial unfolding increased foam stability of whey proteins such that high pressure stabilized the interface between air and water in foam formation. For practical applications, foams prepared with whey proteins help to increase the volume and stability of ice cream foams. High overrun values (close to 100\%) in low-fat ice cream provide soft texture and may yield a mouthfeel similar to regular-fat ice cream.

In the present study, the highest percentage of overrun for WSU-WPC was obtained at $300 \mathrm{MPa}$ for 15 min of HHP treatment at the selected whipping times (Figure 3). However, the 3 treatments (300 and 400 $\mathrm{MPa}$ for $15 \mathrm{~min}, 600 \mathrm{MPa}$ for $0 \mathrm{~min}$ ) were statistically equivalent to each other. The lowest overrun occurred with the 2 treatments at 300 and $400 \mathrm{MPa}$, with come- 


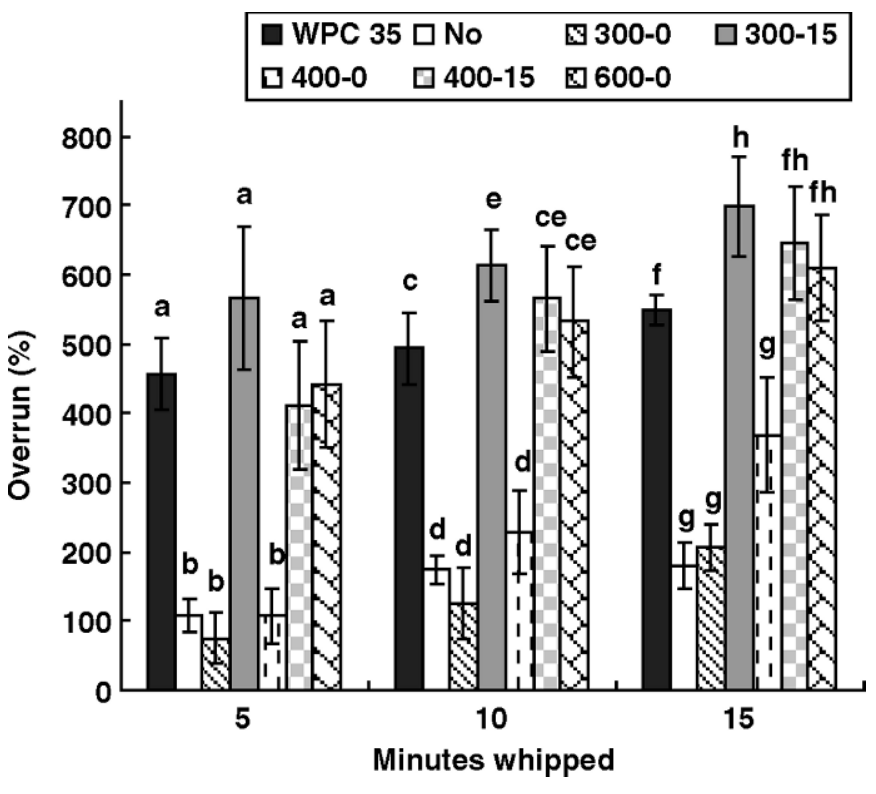

Figure 3. Whipping time and overrun for commercial whey protein concentrate 35 [WPC 35; no high hydrostatic pressure (HHP)] or Washington State University-whey protein concentrate $($ No $=$ no HHP; $300-0=300 \mathrm{MPa}$ for $0 \mathrm{~min} ; 300-15=300 \mathrm{MPa}$ for $15 \mathrm{~min} ; 400$ $0=400 \mathrm{MPa}$ for $0 \mathrm{~min} ; 400-15=400 \mathrm{MPa}$ for $15 \mathrm{~min}$; 600-0: 600 $\mathrm{MPa}$ for $0 \mathrm{~min}$ ) treated with selected HHP-time combinations. ${ }^{\mathrm{a}-\mathrm{h}}$ Different letters denote significant differences for individual whipping times $(P \leq 0.05)$. Vertical lines correspond to standard deviation.

up time, which was statistically equivalent to untreated WSU-WPC for overrun at the selected whipping time (Figure 3). The WSU-WPC that was treated at $300 \mathrm{MPa}$ for 15 min exhibited significantly higher percentage of overrun than untreated WPC 35 when whipped for 10 or 15 min (Figure 3). Untreated WPC 35 exhibited higher percentage of overrun than untreated WSU-WPC (Figure 3). This result is evidence that WPC 35 was fully denatured by heat treatment, which increased foaming capacity. Untreated WSU-WPC was nearly in the native state, which made it less receptive to foaming than partially or profoundly denatured WPC (Kester and Richardson, 1984; Pittia et al., 1996).

Benefits of enhanced overrun are small, however, if the foam cannot be maintained in foods requiring a stable foam, such as ice cream and whipping cream. High-pressure treatment of the whey protein ingredient not only enhanced foaming ability but also foam stability. The largest foam stability was obtained after treatment of WSU-WPC at $300 \mathrm{MPa}$ for $15 \mathrm{~min}$. The shortest stability was observed for untreated WPC 35 (Figure 4). Foam stability of WSU-WPC treated at 300 and 400 $\mathrm{MPa}$ for 15 min was significantly larger than commercial WPC 35 at selected whipping times $(P \leq 0.05$, Figure $4)$. The HHP treatment likely resulted in partial denaturation of the whey proteins, inducing the molten glob-
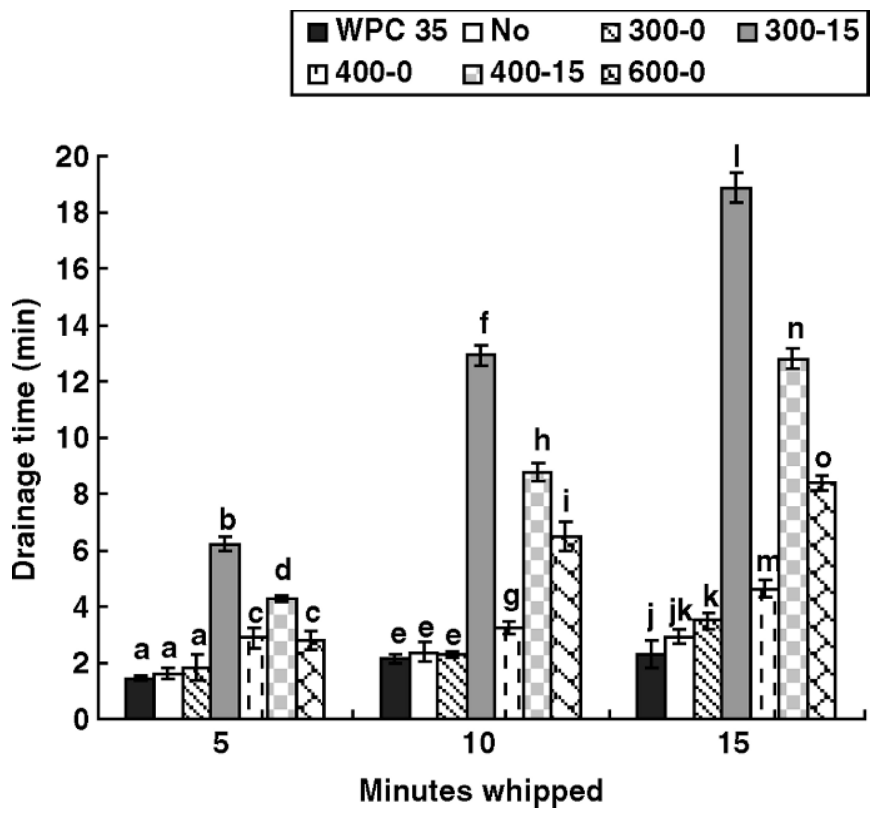

Figure 4. Whipping time and foam stability for commercial whey protein concentrate 35 [WPC 35; no high hydrostatic pressure (HHP)] or Washington State University-whey protein concentrate (No = no HHP; 300-0 = $300 \mathrm{MPa}$ for $0 \mathrm{~min}$; 300-15 = 300 MPa for $15 \mathrm{~min}$; 400 $0=400 \mathrm{MPa}$ for $0 \mathrm{~min} ; 400-15=400 \mathrm{MPa}$ for $15 \mathrm{~min} ; 600-0=600$ $\mathrm{MPa}$ for $0 \mathrm{~min}$ ) treated with selected HHP-time combinations. ${ }^{a-0}$ Different letters denote significant differences for individual whipping times $(P \leq 0.05)$. Vertical lines correspond to standard deviation.

ule state and increasing the hydrophobicity on the surface (Yang et al., 2003; Liu et al., 2005; Lee et al., 2006). Because hydrophobic patches in the open molecule structure stabilize interfaces of proteins between air and water, improved foam stability is attributed to increased hydrophobicity (Pittia et al., 1996). In contrast, WPC 35 powder was drastically denatured by heat treatment, which reduced the patches of hydrophobic affinity. Although WPC 35 yielded large overrun, it did not maintain foam stability. Foam stability of untreated WSU-WPC was inferior to HHP-treated WSU-WPC at the selected whipping times. Untreated WSU-WPC, in the native state, exists in the fully folded form. The native form does not have hydrophobic sites on the surface to maintain foam stability; thus, the foam stability was significantly smaller than HHP-treated WSU-WPC (Figure 4). The foam stability of WPC 35 was also significantly shorter than HHP-treated WSUWPC (Figure 4), likely because WPC 35 proteins were fully denatured, and hydrophobic sites were not available to contribute to foam stability. The WSU-WPC treated at $300 \mathrm{MPa}$ for $15 \mathrm{~min}$ also exhibited greater foam stability than WSU-WPC at $400 \mathrm{MPa}$ for $15 \mathrm{~min}$ (Figure 4); the higher pressure more fully denatured the protein and decreased foam stability. Partial dena- 
$1: 5(20 \mu L)$

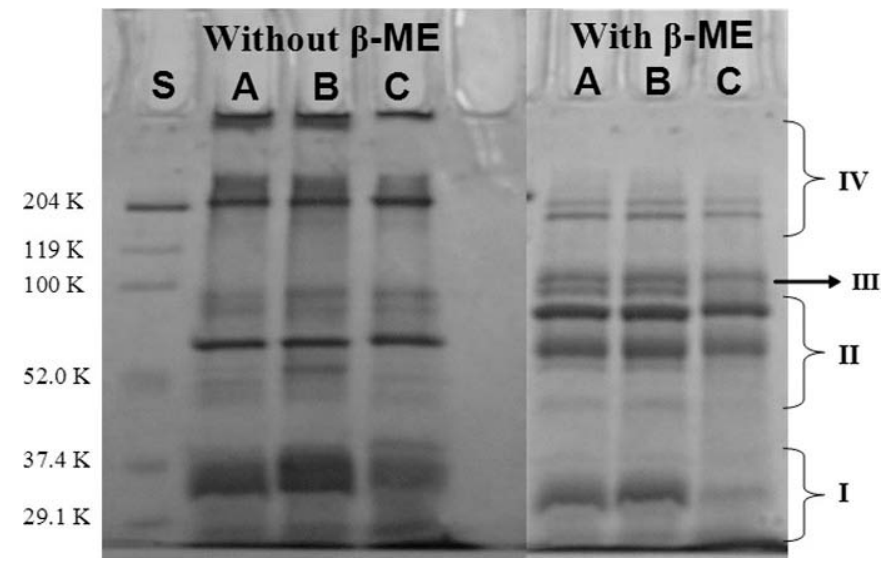

Figure 5. The SDS-PAGE patterns without and with $\beta$-mercaptoethanol ( $\beta$-ME using $10 \%$ gel loaded with standard solution (S), untreated Washington State University-whey protein concentrate (WSU-WPC; A), high hydrostatic pressure-treated WSU-WPC (B), and untreated whey protein concentrate $35(\mathrm{C})$ solutions. I = dimertrimer $\alpha$-LA and $\beta$-LG; II = intermediate aggregates; III = monomeric $\mathrm{BSA} ; \mathrm{IV}=$ large aggregates.

turation is better than complete denaturation, regardless of heat or HHP treatment, for foaming properties. It should be noted that temperature is more difficult to control than pressure during processing.

Overrun and foam stability results suggest foaming properties of WSU-WPC were improved by HHP treatment with $300 \mathrm{MPa}$ for $15 \mathrm{~min}$ or $400 \mathrm{MPa}$ for $15 \mathrm{~min}$. Thus, use of HHP-treated UF fluid whey may potentially improve body and texture of whipping cream and ice cream. If the WSU-WPC had been subjected to a drying process, solubility would be similar to commercial WPC 35, but the high temperature concentrations of spray-drying reduce foaming properties. Although WPC 35 may be appropriate for some applications, HHP-treated UF WPC may have a place in the dairy industry. Such an application would be appropriate for plants that produce cheese and liquid products, frozen desserts, or both, in the same factory.

\section{SDS-PAGE}

The SDS-PAGE results further help to explain improvement in foaming properties of HHP-treated WSUWPC. The 10\% SDS-PAGE gels of untreated WSUWPC, HHP-treated WSU-WPC (300 MPa for $15 \mathrm{~min}$ ), and untreated WPC 35 exhibited 4 major regions. From the bottom to top in Figure 5, according to MW, are exhibited dimers-trimers of $\alpha$-LA and $\beta$-LG (region I), intermediate-sized aggregates (region II), BSA (band III), and large aggregates (region IV, with $\sim 200 \mathrm{kDa}$ of MW; Havea et al., 2002; Liu et al. 2005). Electrophoresis under nonreducing conditions obtained a result wherein large-sized proteins did not enter the stacking gel (Figure 5,6). The protein bands representing dimertrimer $\alpha$-LA and $\beta$-LG (Figure 5, region I) were presented at a smaller concentration for untreated WPC 35 than for HHP-treated WSU-WPC, suggesting a greater number of small MW proteins were present in HHPtreated WSU-WPC than untreated WPC 35 . In addition, several protein bands were noted within the intermediate-sized aggregates region (Figure 5, region II), and a unique protein band corresponding to a molecular weight of about 55,000, not present in the untreated WSU-WPC and WPC 35, was prominent for the HHPtreated WSU-WPC in the $10 \%$ gel. Because the MW of protein bands is the sum of MW of $\alpha$-LA $(12,400)$ and $\beta$-LG $(18,600)$, the unique protein band present in HHPtreated WSU-WPC may indicate $\alpha-\beta$ dimer-trimers formed during HHP treatment. The observed differences in concentrations of large aggregates (Figure 5, region IV) among the 3 WPC treatments were small.

In the presence of $\beta$-ME, left lanes in Figure 5, most large aggregates of the 3 WPC solutions (region IV) observed without $\beta$-ME were dissociated into intermediate forms (Figure 5, region II and III), indicating that large aggregates of WPC were stabilized by disulfide bonds. The unique protein band in the intermediate region of HHP-treated WSU-WPC without $\beta$-ME disappeared with $\beta$-ME (Figure 5, region II). Moreover, a strong band in region I decreased in intensity under reducing conditions (Figure 5, region I). The decrease of intensity in protein bands under reducing conditions means that protein bands included disulfide bonds. The HHP treatment may disrupt large protein aggregates to form smaller proteins that are stabilized by disulfide bonds. Due to HHP treatment, large aggregates of $\beta$ LG, stabilized by disulfide bonds (arising from $\mathrm{SH}$ oxidation), were disrupted to form small proteins (Yang et al., 2001). Whey protein aggregates are disrupted by HHP treatment; HHP results in aggregate disruption into small proteins rather than aggregation. Particle size reduction may affect whey protein functional properties. The particle size reduction and enhancement of protein surface hydrophobicity will contribute to fostering protein adsorption to air-water interfaces, supported by greater foam stability of HHP-treated WSUWPC compared with foam stability of native WSU-WPC or heated-dried WPC 35. Particle size reduction of proteins could be a positive consequence of increased hydrophobic interactions, supporting the formation of a more viscoelastic adsorbed layer between air and water interfaces than large aggregates. Increases in the elasticity of the air-water interface improve the strength of films and enhance foam stability (Bouaouina et al., 2006). Although untreated WPC 35 exhibited almost 


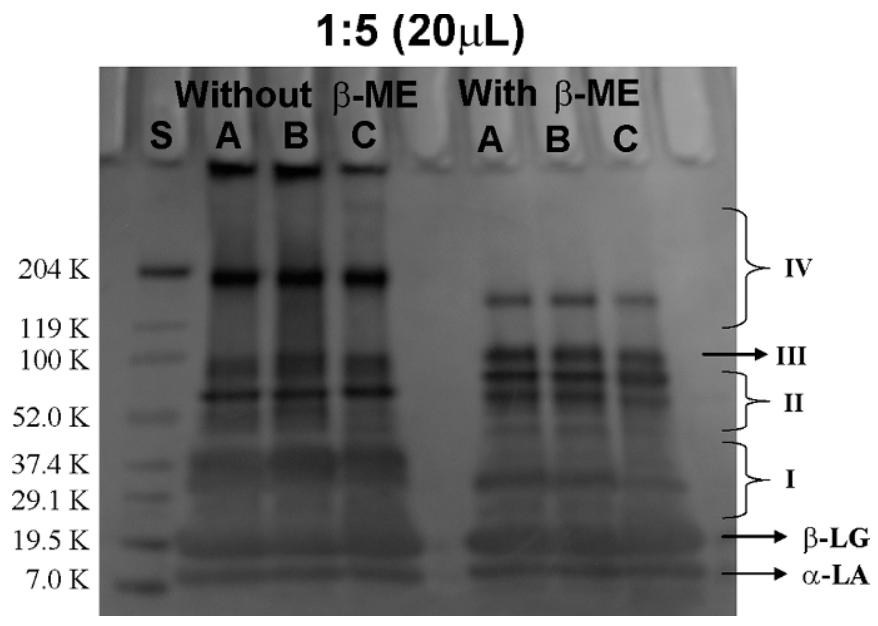

Figure 6. The SDS-PAGE patterns without and with $\beta$-mercaptoethanol ( $\beta-\mathrm{ME}$ using 4 to $20 \%$ gradient gel loaded with standard solution (S), untreated Washington State University-whey protein concentrate (WSU-WPC; A), high hydrostatic pressure-treated WSUWPC (B), and untreated whey protein concentrate 35 (C) solutions. $\alpha$-LA (12.4 kDa); $\beta$-LG (18.6 kDa); I = dimer-trimer $\alpha$-LA and $\beta$-LG; $\mathrm{II}=$ intermediate aggregates; III = monomeric BSA; IV = large aggregates.

equivalent protein bands as HHP-treated WSU-WPC and untreated WSU-WPC in large and intermediate aggregate regions, the protein band in region I almost disappeared under reducing conditions (Figure 5). Disappearance of the protein band indicates that WPC 35 contained more disulfide bonds than the HHP-treated WSU-WPC or the untreated WSU-WPC. Thermal treatments likely induce disulfide bonds; total disulfide bonds of WPC 35 were greater than present in fresh WSU-WPC, as shown by $10 \%$ SDS-PAGE gels.

When the same 3 samples were separated with a 4 to $20 \%$ gradient gel in the absence and presence of $\beta$ ME (Figure 6), protein bands without $\beta$-ME exhibited similarities among the $3 \mathrm{WPC}$. However, the intensity of the $\beta$-LG band was stronger in reducing conditions than in nonreducing conditions (Figure 6). Additionally, protein bands of dimer-trimer $\alpha$-LA and $\beta$-LG, observed in the absence of $\beta$-ME, almost disappeared under reducing conditions (Figure 6, region I). Disruption of dimer-trimer $\alpha$-LA and $\beta$-LG by reducing agent resulted in the formation of monomers of $\beta$-LG and $\alpha$-LA (based on MW of 18.6 and $12.4 \mathrm{kDa}$, respectively, Figure 6). Funtenberger et al. (1997) reported that aggregates of $\beta$-LG are stabilized by disulfide bonds arising from disulfide interchange, which was confirmed by the present findings. Compared with the $10 \%$ Ready Gel without $\beta$-ME (Figure 5 , region I), equivalent patterns of protein bands were exhibited in region I (Figure 6) in the 4 to $20 \%$ Ready Gel, where protein band intensity of HHP-treated WSU-WPC exhibited greater concen- tration than untreated WPC 35. However, a unique protein band was observed in the HHP-treated WSUWPC in the $10 \%$ gel (Figure 5, region II), which was not observed in the 4 to $20 \%$ gel (Figure 6, region II), because the $10 \%$ gel exhibited clearer protein bands in the narrow MW range than protein bands in the 4 to $20 \%$ gel. Although protein bands in the $10 \%$ gels did not allow distinction among the smallest fractions, protein bands in the 4 to $20 \%$ gel enabled visualization of smaller MW fractions of the peptides, especially monomers of $\alpha$-LA and $\beta$-LG, the major whey proteins. The fact that the protein bands exhibited smaller concentrations in the untreated WPC 35 lane than in the HHPtreated WSU-WPC lane with $\beta$-ME (Figure 6) suggests that smaller fractions were present in HHP-treated WSU-WPC than in untreated WPC 35. Overall, more disulfide bonds appeared to be present in WPC 35, based on the results of SDS-PAGE in 4 to $20 \%$ Ready Gel (Figure 6), supporting greater extent of denaturation of untreated WPC 35 compared with untreated WSU-WPC and HHP-treated WSU-WPC. Because WPC 35 was irreversibly denatured by the spray-drying process, subjecting it to HHP is not prudent.

\section{CONCLUSIONS}

The HHP treatment did not significantly reduce fresh WSU-WPC protein solubility at $\mathrm{pH} 4.6$ or 7.0 , suggesting that HHP treatment of WPC is appropriate for applications in selected dairy products. The HHP treatment conditions that promoted functionality of proteins, including large overrun and foam stability, were observed after $300 \mathrm{MPa}$ for $15 \mathrm{~min}$. The SDS-PAGE provided evidence that dissociation of protein aggregates occured and more dimers-trimers were present in HHP-treated WSU-WPC compared with dimers-trimers of untreated WPC 35, which contained large aggregates held together by disulfide bonds. The particle size reduction occurring during HHP treatments of whey proteins partially explains improved foaming properties of WSU-WPC. Because HHP treatment increased overrun and foam stability of fluid WSU-WPC, improvements may potentially enhance body and texture of whipping cream or ice cream.

\section{ACKNOWLEDGMENTS}

The funding for this research was provided by Washington State Dairy Products Commission. We thank Foremost Farms (Baraboo, WI), for supplying ingredients, and Frank Younce (WSU Pilot Plant Manager), Jaydeep Chauhan (WSU MS graduate), and the WSU Creamery staff for assisting with this research. 


\section{REFERENCES}

AOAC. 1990. Number 967.12. Protein in milk: Dye binding method I. Official Methods of Analysis. Vol. 2. 15th ed. Assoc. Off. Anal. Chem., Arlington, VA.

Balny, C., P. Masson, and F. Travers. 1989. Some recent aspects of the use of high pressure for protein investigations in solution. High Press. Res. 2:1-28.

Bouaouina, H., A. Desrumaux, C. Loisel, and J. Legrand. 2006. Functional properties of whey proteins as affected by dynamic highpressure treatment. Int. Dairy J. 16:275-284.

Bradford, M. M. 1976. A rapid and sensitive method for the quantitation of microgram quantities of protein utilizing the principle of protein-dye binding. Anal. Biochem. 72:248-254.

Funtenberger, S., E. Dumay, and J. C. Cheftel. 1997. High pressure promotes $\beta$-lactoglobulin aggregation through $\mathrm{SH} / \mathrm{S}-\mathrm{S}$ interchange reactions. J. Agric. Food Chem. 45:912-921.

Halling, P. J. 1981. Protein-stabilized foams and emulsions. CRC Crit. Rev. Food Sci. Nutr. 15:155-203.

Havea, P., H. Singh, and L. K. Creamer. 2002. Heat-induced aggregation of whey proteins: Comparison of cheese WPC with acid WPC and relevance of mineral composition. J. Agric. Food Chem. 50:4674-4681.

Hercules Technical Information. 2006. AeroWhip ${ }^{\circledR}$ foam stabilizers for use in whipping cream. Bulletin VC-622C. http://www.herc.com/aqualon/product_data/tech/vc622.pdf Accessed Jul. 17, 2007.

Hoffman, L. M. 1996. Processing whey protein for use as a food ingredient. Food Technol. 50:49-52.

Ibanoglu, E., and S. Karatas. 2001. High pressure effect on foaming behavior of whey protein isolate. J. Food Eng. 47:31-36.

Jayaprakasha, H. M., and H. Brueckner. 1999. Whey protein concentrate: A potential functional ingredient for food industry. J. Food Sci. Technol. 36:189-204.

Kanno, C., T. H. Mu, T. Hagiwara, M. Ametani, and N. Azuma. 1998. Gel formation from industrial milk whey proteins under hydrostatic pressure: Effect of hydrostatic pressure and protein concentration. J. Agric. Food Chem. 46:417-424.

Kato, A., Y. Osako, N. Matsudomi, and K. Kobayashi. 1983. Changes in the emulsifying and foaming properties of proteins during heat denaturation. Agric. Biol. Chem. 47:33-37.

Kester, J. J., and T. Richardson. 1984. Modification of whey protein to improve functionality. J. Dairy Sci. 67:2757-2774.

Lee, W., S. Clark, and B. G. Swanson. 2006. Functional properties of high hydrostatic pressure treated whey protein. J. Food Process. Preserv. 30:488-501.
Lee, S. Y., C. V. Morr, and E. Y. W. Ha. 1992. Structural and functional properties of caseinate and whey protein isolate as affected by temperature and pH. J. Food Sci. 57:1210-1214.

Liu, X., J. R. Powers, B. G. Swanson, H. H. Hill, and S. Clark. 2005 Modification of whey protein concentrate hydrophobicity by high hydrostatic pressure. Innov. Food Sci. Emerg. Technol. 6:310 317.

Martin, M. F. S., G. V. Barbosa-Cánovas, and B. G. Swanson. 2002. Food processing by high hydrostatic pressure. CRC Crit. Rev. Food Sci. Nutr. 33:431-476.

Morr, C. V., and E. A. Foegeding. 1990. Composition and functionality of commercial whey and milk protein concentrates: A status report. Food Technol. 44:100-112.

Morr, C. V., B. German, J. E. Kinsella, J. M. Regenstein, J. P. Van Buren, A. Kilara, B. A. Lewis, and M. E. Mangino. 1985. A collaborative study to develop a standardized food protein solubility procedure. J. Food Sci. 50:1715-1718.

Morr, C. V., and E. Y. W. Ha. 1993. Whey protein concentrates and isolates: Processing and functional properties. CRC Crit. Rev. Food Sci. Nutr. 33:431-476.

Parris, N., and M. A. Baginski. 1991. A rapid method for the determination of whey protein denaturation. J. Dairy Sci. 74:58-64.

Pelegrine, D. H. G., and C. A. Gasparetto. 2005. Whey proteins solubility as function of temperature and $\mathrm{pH}$. Lebensm. Wiss. Technol. 38:77-80.

Phillips, L. G., J. B. German, T. E. O’Neill, E. A. Foegeding, V. R. Hanvalkar, A. Kilara, B. A. Lewis, M. E. Mangino, C. V. Morr, J. M. Regenstein, D. M. Smith, and J. E. Kinsella. 1990. Standardized procedure for the measurement of the foaming properties of three proteins: A collaborative study. J. Food Sci. 55:1441$1444,1453$.

Pittia, P., P. J. Wilde, F. A. Husband, and D. C. Clark. 1996. Functional and structural properties of $\beta$-lactoglobulin as affected by high pressure treatment. J. Food Sci. 61:1123-1128.

SAS Institute. 1999. SAS/STAT User's Guide. Version 8.0 Edition. SAS Inst. Inc., Cary, NC.

Yang, J., A. K. Dunker, J. R. Powers, S. Clark, and B. G. Swanson. 2001. $\beta$-lactoglobulin molten globule induced by high pressure. J. Agric. Food Chem. 49:3236-3243.

Yang, J., J. R. Powers, S. Clark, A. K. Dunker, and B. G. Swanson. 2003. Ligand and flavor binding functional properties of $\beta$-lactoglobulin in the molten globule state induced by high pressure. J. Food Sci. 68:444-452.

Young, S. 1999. Pages 1-8 in Whey products in ice cream and frozen desserts. US Dairy Export Counc., Arlington, VA. 